УДК 347.97 (477)

\title{
АДМІНІСТРАТИВНО - ПРАВОВИЙ ХАРАКТЕР ПОВНОВАЖЕНЬ ОРГАНІВ ВИКОНАВЧОЇ ВЛАДИ В СФЕРІ ПРИМУСОВОГО СКАСУВАННЯ ДЕРЖАВНОЇ РЕССТРАЦІЇ ЮРИДИЧНИХ ОСІБ
}

\author{
(C) А. П. Нікітіна \\ Розглядається область владних повноважень державних органів старанною при постанові питання \\ примусової відміни державної реєстрачії юридичної особи, а також автором надані рекомендації по \\ удосконаленню процедури відміни державної реєстрачії. \\ Ключові слова: виконавча влада, примусова відміна, державна реєстращія, владні повноваження, \\ юридична особа
}

The area of imperious credentials of executive authorities is examined at the decision of question of the forced abolition of legal entity state registration, and also recommendations on the improvement of state registration abolition procedure are given by the author.

Keywords: executive power, forced abolition, state registration, imperious credentials, legal entity

\section{1. Ветуп}

Діяльність органів виконавчої влади 3 примусового скасування державної реєстрації юридичних осіб є маловивченим явищем 3 погляду теоретичного визначення сутності правових процесів, які відбуваються за цих правовідносин. Необхідність удосконалення адміністративно-правового регулювання діяльності юридичних осіб в Україні, зокрема застосування до них адміністративних санкцій, з одного боку, та відсутність відповідних предметних наукових досліджень із цієї проблематики - $з$ іншого, обумовлюють актуальність комплексного дослідження правової природи процедури реалізації адміністративних повноважень органами виконавчої влади України при припиненні юридичної особи та її вдосконалення.

\section{2. Аналіз останніх досліджень і публікацій}

На даний час існують лише дослідження окремих елементів участі органів виконавчої влади в процедурі примусового скасування державної реєстрації юридичних осіб у контексті інших питань i відсутнє комплексне дослідження вказаної проблеми. Між тим дослідження питань компетенції органів виконавчої влади в процедурі припинення юридичних осіб здійснено на базі наукових праць відомих вчених - теоретиків із загальної проблематики компетенції органів виконавчої влади: В. Б. Авер'янова, Н. В. Александрової, О. М. Бандурки, О. А. Банчука, В. М. Бевзенка, Ю.П. Битяка, І.Л. Бородіна, А. С. Васильєва, С. В. Ващенка, І. П. Голосніченка, В. М. Горшенєва, П. В. Діхтієвського, А. Т. Комзюка, С. В. Ківалова, Л. В. Коваля, Ю. М. Козлова та інших.

Питання реалізації органами виконавчої влади адміністративних повноважень при примусовому скасуванні державної реєстрації юридичної особи в їхніх працях не отримали детального аналізу, оскільки останні були спрямовані на дослідження більш широких проблем.

Мета та завдання дослідження полягає у встановленні сутності правових відносин, які складаються при реалізації органами виконавчої влади адміністративних повноважень при примусовому скасуванні державної реєстрації юридичної особи.

\section{3. Викладення основного матеріалу}

За своєю суттю вказаний різновид адміністративно-господарських санкцій $\epsilon$ примусовим припиненням суб'єкта господарської діяльності. Ця санкція може бути застосована до будь-якої юридичної особи.

По-перше, постає питання: чи $\epsilon$ правовідносини, які складаються між органом виконавчої влади та юридичною особою 3 приводу застосування до юридичної особи адміністративногосподарських санкцій, публічно-правовими? Подруге, чи є будь-яка адміністративно-господарська санкція (у тому числі примусове скасування державної реєстрації юридичної особи) різновидом господарських санкцій чи ці санкції мають ознаки адміністративних санкцій.

На нашу думку, на перше питання слід відповісти однозначно: правовідносини, які складаються між органом виконавчої влади й суб'єктом господарювання стосовно реалізації повноважень державного органу щодо застосування примусового скасування державної реєстрації, безумовно, $\epsilon$ публічно-правовими відносинами. В. Б. Авер'янов зазначав, що публічно-правові відносини передусім визначають специфіку адміністративної юстиції та відмежовують іiі від інших засобів (способів, форм) захисту прав і свобод людини i громадянина [1]. Г. Ткач визначив специфіку публічно-правових відносин як таких, що будуються за схемою "влада - підпорядкування". Тобто, реалізуючи на практиці суспільні (публічні) інтереси, суб'єкти владних повноважень формують державну або суспільну волю у формі правового рішення й адресують пї іншим учасникам правовідносин - громадянам, організаціям, моделюючи поведінку останніх. А вони, у свою чергу, зобов'язані виконувати встановлені правила (приписи) [2]. 
Орган виконавчої влади як суб'єкт публічноправових відносин володіє певним обсягом повноважень, є учасником різних відносин у різних галузях права з об'єктами управління - фізичними та юридичними особами, іншими органами держави тощо. У разі невиконання іншими учасниками своїх обов'язків у сфері інтересів органу виконавчої влади останній може самостійно застосовувати до порушників заходи державного примусу, оскільки держава надає органу такі права.

Таким чином, повноваження органу виконавчої влади у сфері примусового скасування державної реєстрації юридичних осіб за своїм змістом є адміністративними повноваженнями. Вони реалізують волю держави щодо захисту публічних інтересів у сфері господарських відносин.

Відповідь на друге питання, на нашу думку, має бути суголосна твердженню про публічноправовий характер названих правовідносин. Тобто, відповідно до нашої суб'єктивної думки, що потребує подальшого обговорення, адміністративногосподарські санкції є різновидом адміністративних санкцій, які застосовуються уповноваженими органами влади до суб'єктів господарювання в разі порушень певних правил здійснення господарської діяльності. Отже, діяльність органів виконавчої влади з примусового скасування державної реєстрації юридичних осіб має публічно-правовий характер та регулюються саме адміністративно-правовими нормами.

За визначенням А.Ю. Олійник предметом адміністративного правового регулювання $\epsilon$ суспільні відносини, що виникають, змінюються i припиняються у сфері державного управління. Особливостями відносин, що становлять предмет адміністративного права, є такі: 1) вони виникають у результаті державної владно-управлінської діяльності; 2) суб'єктом таких відносин є виконавчорозпорядчий орган; 3) їх виникнення, зміна чи припинення $є$ результатом свідомої, вольової, цілеспрямованої діяльності [3].

Аналізуючи засоби, за допомогою яких законодавець здійснює правовий вплив на предмет адміністративного права, слід зауважити, що переважно це зобов'язання, заборони та адміністративно-правовий примус [3].

Серед способів як складових елементів адміністративно-правового методу слід виділити авторитарний (наказовий, або владний чи диктаторський) та субординаційний. Авторитарний спосіб виправданий “нерівністю" сторін адміністративних правовідносин, а саме: наявністю владного суб'єкта управління та підвладністю об'єкта управління. Наприклад, відносини податкової адміністрації з будь-яким платником податків [3]. Таке визначення адміністративно-правового методу не можна назвати вдалим, але воно відображає його сутність: наявність у державного органу повноважень здійснювати певний примус на юридичну особу, наприклад, застосовувати різні види санкцій. Особливістю предмета адміністративного права виступає те, що ним є не саме державне управління, а суспільні відносини, які у зв'язку з управлінням виникають. Саме це дає змогу віднести до предмета адміністративного права й недержавні види управлінського впливу (наприклад, у сфері комерційної, підприємницької діяльності). Основне завдання адміністративного права - це правове регулювання організаційних, управлінських відносин у суспільстві (адміністративна діяльність) та правоохоронна діяльність держави [4].

Є. В. Курінний робить висновок, згідно з яким такі спеціальні галузі права, як земельне або фінансове право, своїм самостійним функціонуванням мають бути зобов'язані, у першу чергу, адміністративному праву, а комплексні галузі права, у тому числі банківське, екологічне, митне, господарське право тощо, існують завдяки адміністративному та вказаним вище спеціальним галузям права [5].

Професор С. С. Алексєєв наголошував, що юридичні норми, які входять до комплексних утворень, залишаються за своїми вихідними моментами в головній структурі, в основних галузях, i на них поширюються загальні положення відповідних основних галузей. До вторинної структури вони входять, весь час залишаючись нормами цивільного, кримінального, адміністративного, трудового та іншого права [6].

Є. В. Курінний визначає, що "межі предмета адміністративного права у владно-управлінській сфері мають проходити на рівні регулятивних матеріальних суспільних відносин, об'єкт яких складають публічні інтереси у сфері земельних або фінансових ресурсів. Іншими словами, дія предмета адміністративного права завершується там, де починають виникати регулятивні матеріальні (організаційно-функціональні) відносини однієї 3 двох інших управлінських правових галузей фінансового або земельного права, що мають специфічні та надзвичайно цінні об'єкти регулювання, відповідно, публічні інтереси у сфері фінансів або земельних ресурсів. Причому, якщо зазначені об'єкти фігурують у регулятивних відносинах, які виникають за участю норм, похідних до земельного або фінансового права, у таких комплексних галузях, як екологічне, аграрне, банківське та ін. право, то ці суспільні відносини також потрібно розглядати поза межами предмета адміністративного права" [5]. За зазначеним висновком Є. В. Курінного, адміністративне право серед інших галузей права $\epsilon$ носієм публічних інтересів у тих або інших сферах суспільного життя, тобто адміністративно-правові норми є такими, що певною мірою “втручаються " у правовідносини, які складаються у сфері фінансового, земельного, господарського та інших галузей права. Таке "втручання" має на меті забезпечити інтереси суспільства та держави, в тому числі примусовими методами. На сучасному етапі складність у розмежуванні адміністративного права від інших галузей права полягає в тому, що норми адміністративного права не мають чіткого законодавчого закріплення в кодифікованих 
нормативних актах. Отже, розмежувати адміністративне та господарське право доволі складно, оскільки значна частина відносин, які стосуються предмета господарського права, регулюється нормами адміністративного права i притаманними йому методами. При цьому нормативні акти, які регулюють господарську діяльність, містять як норми, що регулюють господарські відносини, так i норми виключно владного (зобов'язального, або примусового) адміністративного впливу. Це стосується правового регулювання відносин, пов'язаних із застосуванням уповноваженим органом влади адміністративногосподарських санкцій. Ці санкції визначено ГК України, предметом якого є регулювання відносин у сфері господарських відносин. При цьому адміністративно-господарські санкції $є$ складовою державного регулювання господарської діяльності.

Підставою застосування цього виду санкцій $\epsilon$ адміністративно-господарське правопорушення винне, протиправне невиконання чи неналежне виконання суб'єктом господарювання своїх зобов'язань, передбачених чинним законодавством, що порушує права інших суб'єктів господарювання. Відповідно до ч. 3 ст. 217 ГК України, крім зазначених у ч. 2 цієї статті господарських санкцій, до суб'єктів господарювання за порушення ними правил здійснення господарської діяльності застосовуються адміністративно-господарські санкції. Згідно із ч. 4 ст. 217 ГК України, господарські санкції застосовуються у встановленому законом порядку за ініціативою учасників господарських відносин, а адміністративногосподарські санкції - уповноваженими органами державної влади або органами місцевого самоврядування.

Господарські санкції, визначені ч. 2 ст. 217 ГК України, не тотожні адміністративногосподарським санкціям, які визначені ч. 4 ст. 217 ГК України. По-перше, суб'єктом застосування господарських санкцій $\epsilon$, як правило, інший учасник господарських правовідносин. Застосування адміністративно-правових санкцій $є$ прерогативою лише уповноважених органів державної влади або органів місцевого самоврядування, що, у свою чергу, зумовлює публічно-правовий характер відносин, який існує між уповноваженим державним органом i юридичною особою. Загальною підставою, яка спонукає застосування цих санкцій до юридичної особи, $\epsilon$ вчинене правопорушення у сфері господарювання. По-друге, відмінність господарських санкцій від адміністративно-правових санкцій грунтується на характері вчиненого правопорушення у сфері господарської діяльності. Так, істотною рисою, яка зумовлює застосування саме господарських санкцій до юридичної особи, $є$ порушення будь-якого договірного або позадоговірного зобов'язання, яке існує між господарюючими суб' єктами. Стосовно застосування адміністративно-господарських санкцій слід зазначити, що ї застосування зумовлено порушенням господарюючим суб'єктом правил здійснення господарської діяльності. Адміністративно-господарська санкція як різновид адміністративної санкції має певні риси, які визначають іiі адміністративно-правову специфіку: каральний характер (не ставиться за мету компенсувати завдані збитки), застосовується лише компетентним державним органом влади. Наявність відмінностей між господарськими санкціями та адміністративно-господарськими санкціями дає можливість говорити про їх адміністративноправовий характер.

Метою застосування будь-якої санкції є певний вплив на порушника для запобігання його протиправній діяльності або 3 виховною метою. Адміністративно-господарські санкції мають на меті завдати правопорушнику несприятливі економічні та/або правові наслідки (ч. 1 ст. 217 ГК України). 3 аналізу нормативно-правової літератури відомо, що всі заходи адміністративного примусу поділяються зазвичай на три групи (види): адміністративнозапобіжні; адміністративного припинення; адміністративні стягнення.

3. Ф. Татькова виділяє певні особливості застосування адміністративно-господарських санкцій і зазначає, що серед основних рис, які відрізняють адміністративно-господарські санкції від інших господарських санкцій:

- вони застосовуються за порушення норм законодавства щодо умов, вимог чи правил здійснення господарської діяльності;

- повноваженнями щодо ї застосування наділені органи державної влади та органи місцевого самоврядування, до компетенції яких входить контроль за дотриманням відповідних актів законодавства у сфері господарювання;

- правовою підставою їх застосування $\epsilon$ виключно закон, у якому визначається протиправна поведінка суб' єктів господарювання [6].

$$
\text { Як уже підкреслювалося, суб'єктом }
$$
застосування адміністративно-господарських санкції $\epsilon$ державні органи влади. Застосування санкцій $\epsilon$ однією 3 форм державного управління. Державне управління являє собою свідомий і цілеспрямований вплив, що здійснюється спеціальними уповноваженими органами державної влади у певній сфері (у тому числі у сфері господарських відносин) в обсязі повноважень, на підставі і в порядку, визначеному законодавством, 3 використанням адміністративного примусу.

Оскільки адміністративно-господарські санкції $\epsilon$ певною формою державного примусу, доцільно говорити про адміністративно-правовий характер правовідносин, які складаються при застосуванні вказаних санкцій між виконавчим органом влади та суб'єктом господарської діяльності. Як зазначає В.Б. Авер'янов, адміністративно-правові відносини завжди мають державно-владний характер, тобто один із суб'єктів завжди наділений державою владними повноваженнями щодо інших учасників адміністративно-правових відносин [3].

При цьому необхідно прислухатися до пропозиції В. С. Щербини, яка пропонує виокремити 
положення про адміністративно-господарські санкції iз ст. 217 ГК України в самостійну статтю, зокрема, ст. 217-1 ГК України, з метою закріплення специфіки цих санкцій, відокремлення їх від інших господарських санкцій [6]. Варто погодитися 3 думкою В.С. Щербини про те, що адміністративногосподарські санкції є засобом господарськоправової відповідальності. Відповідно до ч. 4 ст. 3 ГК України, сферу господарських відносин становлять господарсько-виробничі, організаційно-господарські та внутрішньогосподарські відносини.

Відповідно до ГК України, відносини, які складаються між органами влади з приводу реалізації їх організаційно-господарських повноважень та юридичними особами, є діяльністю держави в особі іiі органів та органів місцевого самоврядування, що спрямована на забезпечення публічних інтересів шляхом використання засобів впливу на господарські відносини. Згідно із ч. 6 ст. 3 ГК України, під організаційно-господарськими відносинами розуміються відносини, що складаються між суб'єктами господарювання та суб'єктами організаційно-господарських повноважень у процесі управління господарською діяльністю.

I. М. Кравець зазначає, що організаційногосподарські відносини при їх реалізації не мають владного впливу на суб'єктів господарювання, оскільки організаційно-господарські відносини нерозривно пов'язані 3 майновими відносинами, формою їх реалізації $є$ організаційно-господарське зобов'язання, адміністративно-правовим відносинам не властива така ознака [4].

За визначенням C.I. Юшиної, адміністративногосподарські санкції, визначені ГК України, можна розглядати як заходи адміністративного припинення правопорушень [5]. Ці висновки можуть видатися спірними з огляду на позиції ряду вчених, серед яких А. Папаїка, Н. М. Шевченко [6], котрі вважають, що адміністративно-господарські санкції $\epsilon$ різновидом господарських санкцій. Враховуючи, що орган виконавчої влади, який застосовує адміністративногосподарські санкції, не є суб'єктом організаційногосподарських відносин, твердження про господарсько-правовий характер адміністративногосподарських санкцій $є$ помилковим.

\section{дослідження \\ 4. Висновки та перспективи подальшого}

Орган виконавчої влади, який застосовує до юридичної особи примусові методи впливу (адміністративно-господарські санкції), виступає не як суб'єкт, який має господарську компетенцію, а як суб'єкт владних повноважень, який реалізує адміністративно-правову компетенцію.
Застосування суб'єктом владних повноважень до юридичної особи примусового скасування державної реєстрації $\epsilon$ проявом його адміністративно-правових повноважень, особливістю яких $\epsilon$ те, що державний орган застосовує ці повноваження у сфері господарських відносин у зв'язку 3 їх порушенням (наявністю складу адміністративного правопорушення). Ці повноваження мають на меті захистити саме публічний інтерес. При цьому суб'єкти владних повноважень виступають як носії публічного інтересу.

Більш детальне дослідження адміністративноправового характеру повноважень органів виконавчої влади у сфері примусового скасування державної реєстрації юридичних осіб буде розглянуто в подальших працях.

\section{Література}

1. Права громадян у сфері виконавчої влади: адміністративно-правове забезпечення реалізації та захисту [ Текст] / за заг. ред. В.Б. Авер'янова. - К. : Наукова думка, 2007. $-582 \mathrm{c}$.

2. Ткач, Г. Поняття владного повноваження [Текст]/ Г. Ткач // Вісник Львівського університету. Серія юридична. - 2009. - Вип. 49. - С. 101-105.

3. Правознавство [Текст]: підручник / за ред. А. І. Берлач, Д. О. Карпенко, В. С. Ковальський, А. М. Колодій, А. Ю. Олійник. - К. : Юрінком Інтер, 2004. $-752 \mathrm{c}$.

4. Коваль, Л. В. Адміністративне право [Текст]: курс лекцій / Л. В. Коваль. - К. : Вентурі, 1998. - 208 с.

5. Курінний, Є. В. Адміністративне право України: тенденції трансформації в умовах реформування [Текст]: навч. посіб. / С. В. Курінний. - Д. : Юридична академія МВС України, 2002. - 92 с.

6. Бахрах, Д. Н. Административное право [Текст] : учеб. для вузов / Д. Н. Бахрах. - М., 1996. - 355 с.

\section{References}

1. Aver'yanova, V. B. (Ed.) (2007). Rights for citizens are in the field of executive power: administrativno-pravove providing of realization and defence. Kiev: Scientific thought, 582.

2. Tkach, G. (2009). Ponyattya imperious plenary powers. Announcer of the Lviv university. Series are legal, 49, $101-105$.

3. Berlach, A. I., Karpenko, D. O., Koval'skiy, V. S., Kolodiy, A. M., Oliynik, A. Yu. (Ed.) (2004). Jurisprudence. Kiev: Yurinkom Inter, 752.

4. Koval, L. V. (1998). Administrative law. Kiev: Venturi, 208.

5. Kurinniy, E. V. (2002). Administrative law of Ukraine: tendencies of transformation are in the conditions of reformation. Legal academy of MVS of Ukraine, 92.

6. Bakhrakh, D. N. (1996). Administrativnoe right. Moscow, 355.

Нікітіна Аліна Петрівна , кандидат юридичних наук, доцент , кафедра «Правознавство», СЕГІ ТНУ імені В.I. Вернадського, вул. Лізи Чайкіної, 80, м. Севастополь, 299058

E-mail:nikitina7777@mail.ua 